\section{Contrast study in umbilical venous line extravasation}

A preterm infant born at 25 weeks' gestation, birth weight $730 \mathrm{~g}$, had an umbilical venous catheter (UVC) inserted on day 1. The line bled and flushed freely at $5 \mathrm{~cm}$ and would not sample beyond this position. Supine abdominal X-ray (AXR) showed vertical position of the line with the tip at T11-T12. This was recognised as a suboptimal position but attempts to secure intravenous access with a percutaneous long line was unsuccessful. The UVC remained in situ and was used to administer total parenteral nutrition. Baby gradually became unstable on day 3 with abdominal distension, metabolic

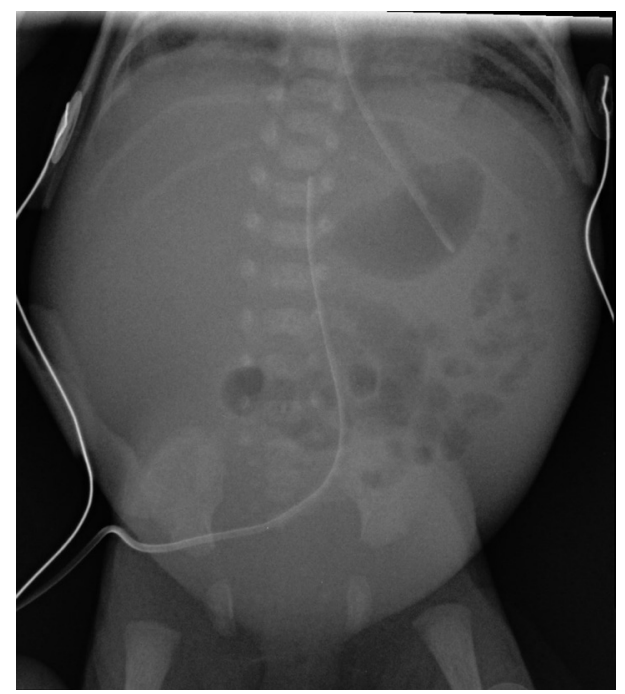

Figure 1 Low-lying umbilical venous catheter.

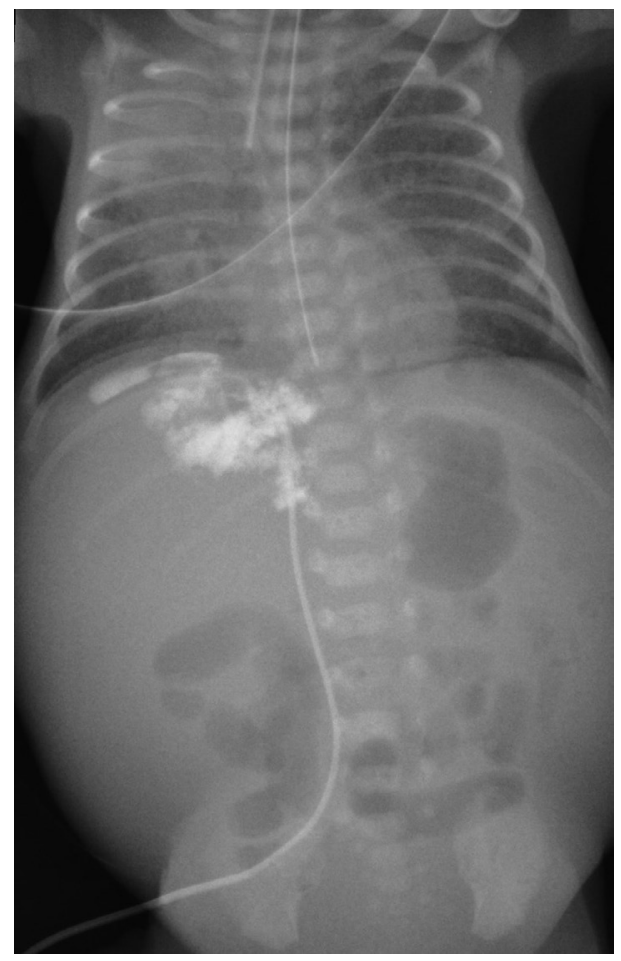

Figure 2 Contrast study showing extravasation. acidosis, rising urea and hyperglycaemia. An AXR on day 4 showed low-lying UVC (L1 position) and featureless bowel gas pattern. UVC extravasation was suspected, and this was confirmed with contrast injection. The UVC was removed and an improvement in bloods, oxygen requirement and blood glucose was seen within 24 hours. Baby recovered without further complications.

Extravasation is a known complication of umbilical venous catheter (UVC) placement. ${ }^{1}$ It has been reported to present in a manner mimicking necrotising enterocolitis and can lead to significant morbidity or mortality (figure 1$)^{2}$ In this case, contrast administration combined with a degree of clinical suspicion demonstrated hepatic extravasation as the cause of the patient's deterioration. There is evidence routine contrast use in checking tip positions improves long line positioning ${ }^{3}$ and British Association of Perinatal Medicine (BAPM) has included this in it's central access guidance. ${ }^{4}$ Here we demonstrate it can be used to check the position of umbilical central access and to demonstrate extravasation (figure 2).

\section{Susan Rutendo Kamupira ๑ , James Dexter Tarr, Minju Kuruvilla}

St Mary's Hospital, Neonatal Intensive Care Unit, Manchester University NHS Foundation Trust, Manchester, UK

Correspondence to Dr Susan Rutendo Kamupira, St Mary's Hospital, Neonatal Intensive Care Unit, Manchester University NHS Foundation Trust, Manchester M13 9WL, Greater Manchester, UK; Susan.Kamupira@mft.nhs.uk

Contributors JDT: writing up the report and obtaining parental consent. SRK: writing up the report. MK: named consultant, writing up the report.

Funding The authors have not declared a specific grant for this research from any funding agency in the public, commercial or not-for-profit sectors.

Competing interests None declared.

Patient consent for publication Parental/guardian consent obtained.

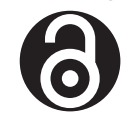

\section{OPEN ACCESS}

Open access This is an open access article distributed in accordance with the Creative Commons Attribution Non Commercial (CC BY-NC 4.0) license, which permits others to distribute, remix, adapt, build upon this work non-commercially, and license their derivative works on different terms, provided the original work is properly cited, appropriate credit is given, any changes made indicated, and the use is non-commercial. See: http://creativecommons.org/licenses/by-nc/4.0/.

(C) Author(s) (or their employer(s)) 2021. Re-use permitted under CC BY-NC. No commercial re-use. See rights and permissions. Published by BMJ.

\section{Check for updates}

To cite Kamupira SR, Tarr JD, Kuruvilla M. Arch Dis Child Fetal Neonatal Ed Epub ahead of print: [please include Day Month Year]. doi:10.1136/ archdischild-2020-321081

Received 4 November 2020

Accepted 4 January 2021

Arch Dis Child Fetal Neonatal Ed 2021;0:F1

doi:10.1136/fetalneonatal-2020-321081

\section{ORCID iD}

Susan Rutendo Kamupira http://orcid.org/0000-0003-3583-7268

\section{REFERENCES}

1 Hargitai B, Toldi G, Marton T, et al. Pathophysiological mechanism of extravasation via umbilical venous catheters. Pediatr Dev Pathol 2019;22:340-3.

2 Baker J, Imong S. A rare complication of neonatal central venous access. Arch Dis Child Fetal Neonatal Ed 2002;86:61F-2.

3 Reece A, Ubhi T, Craig AR, et al. Positioning long lines: contrast versus plain radiography. Arch Dis Child Fetal Neonatal Ed 2001;84:129F-30.

4 British Association of Perinatal Medicine 2020. Use of central venous catheters in neonates, 2018. 